This item is the archived peer-reviewed author-version of:

The Information and Arena model : its value and limitations

\title{
Reference:
}

Van Aelst Peter, Walgrave Stefaan.- The Information and Arena model : its value and limitations

Political communication - ISSN 1058-4609 - Philadelphia, Taylor \& francis inc, 36:1(2019), p. 203-207

Full text (Publisher's DOI): https://doi.org/10.1080/10584609.2018.1548414

To cite this reference: https://hdl.handle.net/10067/1576750151162165141 


\section{The Information and Arena model: its value and limitations}

The book "How Political Actors use the Media" is the result of a long intellectual journey. Frustrated by the explosively growing work on media and politics and, especially, by our own inability to get a grip on that literature and to categorize the existing knowledge in a parsimonious and satisfying way, we thought and discussed a lot about how to 'organize' the domain of media and politics. Numerous brainstorms and many (quite fundamental) revisions resulted in a literature review paper published in Journal of Communication titled "Information and Arena. The Dual Function of the News Media for Political Elites". We argued that conceptualizing two broad functions the mass media have for political actors-being at the same time a source of information nurturing their political work and an arena to reach out to the public-is a useful model to consolidate the work on media and politics. We consider Information \& Arena not as a theory of media and politics, it does not 'explain' anything, but rather as a model or a framework that helps to analyze the mutual relationship between political actors and the mass media and that draws attention to the different dimensions of this intricate relationship. Not very modestly, we asked leading scholars in the field to critically expand, challenge or revise the Information and Arena model in the edited book that is discussed in this Forum. We are happy and honored that this book now gets attention in this Forum. And, we are deeply thankful for the thoughtful reactions of colleagues we regard highly.

Both Forum contributions challenge us to broaden the Information and Arena (I\&A) model or at least to link it with different strands of literature. Jay Blumler correctly notes that literature on political marketing and campaign professionalization is missing and that the role of political actors' own communication strategy is underdeveloped. Bahador, Entman and Knupfer draw attention to the growing polarization and fragmentation in politics and mass media and suggest that the rules with regard to access to the media arena have changed. Added to that, they doubt whether our strict definition of what we consider to be 'political elites' is sufficiently covering 'the powerful' and they suggest that we think about elites and their relationship to the media more broadly. These are fair comments. We are grateful that both contributions adopt the Information and Arena perspective and think along trying to improve it. Remarkably, both critical reactions challenge us to think more and better especially about the arena function of the mass media; that the media form a source of information for elites does not seem to be very controversial. Or is that this function is still largely overlooked in the literature? Overall, our general reaction to both appeals to broaden and extent the I\&A-model is one of mitigated reluctance. We prefer a (rather) sharp knife to dissect fewer species above a blunter instrument with a broader use (think: hammer). Although we admit there is no right option with regard to the aggregation level a theoretical framework should be situated on -it is more a matter of epistemological 'taste' - we believe the I\&A framework to be more useful when used in the strict sense than when interpreted broadly. We now make this claim more concrete in reacting to the specific points raised by Blumler and Bahador et al.

Blumler signals the I\&A-model's limited attention for the concrete strategies political actors employ to enter the media arena. We neglect the ample literature on campaigns and on the 
professionalization of political advocacy. Although the book contains a chapter on news management strategies (by Strömbäck \& Esser), we accept this critique. The thing is that the ample campaign literature very often does not address specific strategies to get into the media but rather looks at campaigns more generally. For instance in the article of Tenscher and colleagues (2016), suggested by Blumler, political consultants are asked to evaluate more than thirty 'strategic components' of professional campaigning ranging from 'using opinion polls', over 'communication with voters via Facebook' to 'having an impact on media's agenda'. This illustrates that most of this literature does not deal with media-targeted communication, what the I\&A model is dealing with, but more generally with putting together the right strategy, mediatized or not, to win a political fight. In that sense it is no surprise that according to these political consultants from a wide range of European countries the 'choice of the right strategy' is believed to be most important to win a campaign. This being said, we agree with Blumler's recommendation that we know relatively little about the media strategies of political actors; scholarly work that tries to provide more insight in how exactly politicians try to enter the media arena should be welcomed. An advantage of such an approach focusing on strategies is that the agency political actors have-they are not just the 'victims' of news media's selection routines but can actively influence the selection journalists make and how events are covered-becomes more evident (Van Aelst, Thesen, Walgrave, \& Vliegenthart, 2014). Also, as Blumler says, devoting more attention to actors' media strategies could insert a 'dynamic component' into the model. Additional assets of such an approach are, for example, that it allows to link the I\&A model with recent and increasingly relevant work on how politicians use social media to enter or influence the traditional media (e.g. Wells et al., 2016) or that the model can be connected to the booming literature on mediatization stating that political actors have, nowadays, fully internalized the media logic and, almost unconsciously, incorporate the media consequences of all they undertake (Esser \& Strömbäck, 2014). All in all, Blumler's suggestion that we need to devote more attention to how actors try to play the media arena is well taken. It draws attention to one crucial component of the way the media can be used by political actors and it is perfectly compatible with the core idea the model is built on.

The suggestions and remarks by Bahador and colleagues go a step further. They point to the growing fragmentation of the news media and their increasing partisan bias, which makes politicians "speaking in parallel media arenas to their own partisans". Their own fascinating research on the different ways 'elites' are understood in left- versus right-wing US media outlets further underscores this point. While in left-wing outlets economic and corporate groups are most mentioned as being elites, liberal and democratic elites dominate in the right-wing media. That these different conceptualization of elites resonates with whom different voters perceive elites to be makes this finding even more relevant. In terms of the I\&A model, the consequences of highly partisan media are obvious. Political actors do not have to painfully gain access to the media arena by adapting their communication and by obeying to the rules of media logic. Instead they get easy and free access to friendly media outlets. In a sense, in such a system, the media no longer perform a gatekeeping function but become the cheerleaders, or the media arm, of specific parties. These outlets, then, can no longer be considered as an 'arena' in which fights with political competitors are fought out, but 
rather as free podia providing favorable publicity to befriended politicians. While the US experience may reflect to some extent a broader trend of increasing partisan slant of the media across the globe, the way the US media landscape has evolved in a partisan direction (Stroud, 2011), driven by the gradually increasing segregation of the political leaning of its audiences and fueled by the polarization evident across elites, seems exceptional to us. For instance, recent data of the Reuters Institute (2018) show that, in the US, trust in specific media outlets is mainly determined by partisan leaning. People on the right are highly skeptical of traditional media outlets, and only trust partisan outlets like Fox News and Breitbart, while people on the left believe the opposite. And, since Trump's election, news consumers in the US expect their favorite medium to be consistently supportive or critical for the president. The situation in many Western democracies, though, is very different. In countries like Denmark, Belgium and Germany there are few differences in the level of trust in specific outlets between people across the political spectrum. There (still) is much more one media arena with the different outlets sharing a similar agenda in terms of issues, actors and tone of coverage, with all outlets more or less applying similar inclusion and exclusion rules, and with, as a consequence, a much less partisan and polarized media system. We admit that the I\&A model is mainly based on the situation in these countries, where the news media are not in the first place a political actor driven by partisan goals but where rather a commercial media logic prevails. Access to the media arena, in such a situation, is not a matter of bias towards certain political actors or ideas but, at worst, more structural and based on an appetite for what is conflictual and sensational. Probably it is the sheer size of its media consumer market and the fact that it is a bipartisan system that make partisan media also commercially viable in the US. Again, there are signs of growing polarization and partisan bias in the media in several European democracies as well. For instance, in Hungary, the growing direct influence of Prime Minister Viktor Orbán on the news coverage of the public broadcaster has influenced the extent to which left wing versus right wing voters trust this institution (Newman, Fletcher, Kalogeropoulos, Levy, \& Nielsen, 2018). But most democracies are far off from the gradually further balkanizing US media system. For now, we are inclined to consider the findings and argument of Bahador et al. as an example of US exceptionalism rather than as the new normal. Yet, Bahador et al's criticism draws attention to a much needed qualification of the I\&A model: it only describes the interaction between political actors and the mass media in a valid way in a political system where the mass media are autonomous vis-à-vis political actors and where, as a consequence, gaining access to the mass media is a matter of political status, hard work or smart communication.

The I\&A model is specifically designed to describe and scrutinize how politicians interact with and depend on the mass media. Politicians (or parties) have specific goals that explain why they use the media both as a source of information and as an arena for political communication. With regard to the arena function it is obvious that politicians need access to it to connect to the public. With regard to the information function politicians need constant input about the main problems their societies are struggling with. Bahador et al. correctly state that elites are more than politicians. Elites, and even the concept of political actors, might include business men, bankers and even leading cultural figures. Yet, these people have fundamentally different goals and motives, and this means that their 
dealings with the media, and the function the mass media have for them, may be very different. For example, many business elites and also lobbyists avoid rather than seek media attention; they have more to lose than to win by standing in the media spotlights. We are optimistic that the I\&A model may be useful as an analytical tool to even tackle the media use of CEO's, bankers, celebrities, lobbyists and interest group leaders. But it will be paramount to take the different incentives driving those groups into account.

We would also like to react on Bahador et al's critique that our model lacks the crucial third player in the political communication triangle, being public opinion. It is true that one can only start to try to understand how media and politicians interact when one takes the public into account. But our functional approach aims to sharpen our look at how the media matter for politicians and fully adopts their point of view. Courting the public, catering to the needs of as many people as possible, gaining popularity and, ultimately, being positively sanctioned at election times is what drives politicians more than anything else. Our model places the agency to reach that goal with the politicians, but the public is the absolute arbiter of the game. When politicians want to enter the media arena, they do it to be visible for the public. When they carefully frame their message in the media, they do it to convince the public. When they adopt media information in their work, they do it because they want to act on current problems the public cares about. When they react on media attention for problems they aim to show to the public that they are responsive. So, from the perspective of politicians, their entire interaction with the mass media is aimed at the third player: the public. But that, we believe, does not mean that the public should be part of the model. The public is, almost by definition, incorporated in the motives and goals of the politicians.

Finally, Blumler challenges us to think about the normative implications of the I\&A approach. We confess that conceptual clarity and organizing the current literature were our only intentions. Naturally, many normative questions come to mind when thinking about how politicians can and should use the media. Is it a good thing that media coverage informs politicians? Would it not be better that politicians rely on more specialized and expert sources? Should maximize one's media attention be a natural goal of the job of politician? Does the careful crafting of media messages lead to misinforming instead of informing the audience? We don't feel the need to answer these questions here; each of the functions of the mass media deserve to spur a normative debate. Yet we feel confident to make at least one normative claim derived from the I\&A model. Democracy has a lot to lose when media arenas become narrower and ideologically homogenous. This is not only the case because ordinary citizens do not hear the other voice anymore, but also because it might narrow the diversity of the information menu of politicians. Public opinion is diverse and an important role of politicians is to look for common ground and make policy for all citizens. The more partisan and segmented the media, the less diverse the information about problems, solutions and public opinion politicians get. Think about Donald Trump who mainly watches Fox News which does not exactly help him to get an idea of the shared understanding of the issues at stake. 
In closing, we really liked the suggestions of the authors of this Forum to expand the I\&A model and include different types of actors, to take different media contexts into account, to focus more on the strategies political actors use in their dealings with the media, to make the role of the public more explicit, and to think about the normative implications. We are especially delighted the comments allowed us to think again about the scope of the model that we probably took for granted. The model applies to situations where traditional political actors such as politicians use the traditional media in a context of a common and not overly partisan media arena with a shared media logic. We understand that in a changing world where both politicians and journalists are under pressure these 'ideal' conditions might change sooner rather than later. But we are confident that the underlying logic of political actors needing information and visibility, and the media somehow offering these two goods, withstands structural changes in how politicians will use the media in years to come.

\section{Bibliography}

Esser, F., \& Strömbäck, J. (2014). A Paradigm in the Making: Lessons for the Future of Mediatization Research. In J. Strömbäck \& F. Esser (Eds.), Mediatization of Politics: Understanding the Transformation of Western Democracies (pp. 223-242). Basingstoke: Palgrave Macmillan.

Newman, N., Fletcher, R., Kalogeropoulos, A., Levy, D. A. L., \& Nielsen, R. K. (2018). Reuters Institute Digital News Report 2016. Oxford, England: Reuters Institute for the Study of Journalism.

Stroud, N. J. (2011). Niche news: The politics of news choice: Oxford University Press on Demand.

Tenscher, J., Koc-Michalska, K., Lilleker, D. G., Mykkänen, J., Walter, A. S., Findor, A., . . Róka, J. (2016). The professionals speak: Practitioners' perspectives on professional election campaigning. European Journal of Communication, 31(2), 95-119. doi:10.1177/0267323115612212

Van Aelst, P., Thesen, G., Walgrave, S., \& Vliegenthart, R. (2014). Mediatization and Political AgendaSetting: Changing Issue Priorities. In F. Esser \& J. Strömbäck (Eds.), Mediatization of Politics. Understanding the Transformation of Western Democracies (pp. 200-222). Basingstoke: Palgrave.

Wells, C., Shah, D. V., Pevehouse, J. C., Yang, J., Pelled, A., Boehm, F., . . Schmidt, J. L. (2016). How Trump Drove Coverage to the Nomination: Hybrid Media Campaigning. Political Communication, 33(4), 669-676. doi:10.1080/10584609.2016.1224416 